\title{
IMPLEMENTASI TOTAL QUALITY MANAGEMENT DALAM MENINGKATKAN MUTU PENDIDIKAN DI MA MAMBA'UL HISAN SIDAYU GRESIK
}

\author{
Ahmad Afghor Fahruddin \\ Sekolah Tinggi Agama Islam Daruttaqwa Suci Gresik \\ aaf_evol@yahoo.com \\ DOI: https://doi.org/10.35719/jieman.v2i1.15
}

\begin{abstract}
Abstrak
Masa sekarang ini, pendidikan menjadi prioritas menanamkan nilai-nilai moral pada generasi di Indonesia, sehingga menjadi urgen menemukan cara bagaimana meningkatkan mutu pendidikan. Oleh karenanya dalam meningkatkan kualitas mutu pendidikan harus menciptakan sumber daya manusia yang mampu memecahkan masalah global dalam dunia pendidikan. Total Quality Management (TQM) adalah konsep manajemen sekolah dalam melaksanakan pendidikan serta diharapkan bisa memberikan perubahan yang lebih baik sesuai dengan pembangunan, tuntutan dan dinamika masyarakat. Madrasah Aliyah (MA) Mamba'ul Hisan Sidayu Gresik telah menerapkan empat konsep dalam TQM untuk meningkatkan kualitas mutu pendidikan: pertama, mutu dalam proses penerimaan siswa di lembaga ini; kedua, kepuasan pelanggan yaitu memenuhi kebutuhan peserta didik; ketiga, perbaikan terus menerus dalam rekrutmen guru yang berkualitas dan mempunyai keahlian lainnya dan setiap akhir semester melakukan evaluasi terhadap hasil kinerja guru, peningkatan kualitas pembelajaran; dan keempat, melibatkan seluruh komponen yang ada di lembaga pendidikan.
\end{abstract}

Kata Kunci: total quality management, mutu pendidikan, madrasah

\section{Abstract}

Nowadays, education is a priority to instill moral values in generations in Indonesia. So it becomes urgent to find ways to improve the quality of 
education. Therefore, in improving the quality of education, it must create human resources capable of solving global problems in the world of education. Total Quality Management (TQM) is the concept of school management in implementing education and is expected to provide a better change in accordance with the development, demands, and dynamics of the community. Madrasah Aliyah (MA) Mamba'ul Hisan Sidayu Gresik has applied four concepts in TQM to improve the quality of education quality, first, the quality of the student admission process at this institution; second, customer satisfaction is to meet the needs of students; third, continuous improvement in the recruitment of qualified teachers and other experts and at the end of each semester evaluates the performance of teachers, improving the quality of learning; and fourth, it is involving all components in educational institutions.

Keyword: total quality Management, quality education, madrasah

\section{Pendahuluan}

Pada era globalisasi ini dunia pendidikan telah dituntut untuk selalu bisa mengikuti perkembangan kemajuannya terutama di bidang teknologi maupun informasi yang berkembang sangat pesat, harapannya supaya bisa selalu melakukan perbaikan dan meningkatkan kualitas/mutu pendidikan. Pendidikan mempunyai peran sangat penting dalam memajukan suatu negara serta membentuk sebuah watak dan karakter dalam suatu bangsa. Pendidikan termasuk salah satu faktor tumbuh berkembangnya ekonomi negara. Pendidikan juga sebagai tolok ukur kemajuan dan kualitas dari suatu bangsa, maka keberadaan pendidikan dapat menciptakan masyarakat cerdas, berwawasan luas serta beradab.

Penyelenggaraan pendidikan formal baik pada jenjang pendidikan dasar, menengah maupun tinggi memiliki kebijakan dan permasalahan kritis di mana yang menjadi isu utamanya adalah mengenai kualitas mutu pendidikan. Untuk itu peningkatan mutu terhadap pendidikan menjadi hal yang sangat penting untuk diperhatikan. Adapun ukuran mutu dalam dunia pendidikan antara lain adalah sekolah memiliki akreditasi A, lulusan diterima di sekolah terbaik, hasil ujian nasional masuk dalam kategori terbaik, banyaknya guru yang ahli dan professional di bidangnya, peserta 
didik memiliki prestasi beragam kompetensi, serta memiliki karakter yang baik. ${ }^{1}$

Implementasi TQM dalam dunia pendidikan telah banyak di lakukan di Indonesia, para pakar banyak membahasnya namun masih pada ranah pendidikan secara umum tidak pada pendidikan agama. Padahal pendidikan agama punya peran urgen dalam menanamkan moral kepada generasi bangsa Indonesia saat ini. Oleh karenanya dalam kurikulum 2013 pendidikan agama Islam mendapat perhatian khusus dan diberikan tambahan jam belajar. Supaya dapat mencetak dan melahirkan generasi bangsa yang bermoral, beriman dan bertaqwa sesuai, itu semua dapat terwujud bila peningkatan mutu pendidikan terlaksan. Selain itu, peran guru menjadi urgen dalam implementasi TQM di lembaga pendidikan karena mereka berinteraksi langsung dengan peserta didik selama proses pembelajaran.

\section{Pembahasan}

\section{Total Quality Management (TQM)}

Total Quality Management (TQM) atau yang biasa disebut Manajemen Mutu Total (MMT) dapat dipahami secara utuh dari beragam pengertian tentang TQM itu sendiri. ${ }^{2}$ Beberapa pendapat para pakar tentang makna Total Quality Management (TQM) antaranya yaitu: TQM merupakan penerapan metode dan pengetahuan Sumber daya manusia untuk: memperbaiki material dan jasa, memperbaiki semua proses dalam organisasi, dan memperbaiki upaya memenuhi kebutuhan para pemakai produk dan jasa. ${ }^{3}$ TQM adalah memaksimal semua fungsi dari organisasi yang dibangun berdasarkan konsep mutu, kerja tim, serta kepuasan pelanggan. ${ }^{4}$ TQM merupakan sistem manajemen dalam meningkatkan kualitas secara keseluruhan dalam persaingan yang berorientasi

${ }^{1}$ Ridwan Abdullah Sani, Isda Pramuniati, Anise Mucktiany, Penjaminan Mutu Sekolah (Jakarta: Bumi Aksara, 2015), 1.

${ }^{2}$ Miftakhul Munir, Keberadaan Total Quality Management dalam Lembaga Pendidikan (antara Prinsip Implementasi dan Pilar TQM dalam Pendidikan), Realita, Vol. 16, No. 1 Tahun 2018, 6.

${ }^{3}$ ibid. 7 .

${ }^{4}$ West-Burnham, Managing Quality in School, (London: Prentice Hall, 1997), 74 . 
padakepuasan pelanggan dengan melibatkan totalitas kerja anggota organisasi. ${ }^{5}$

Berdasarkan pengertian TQM di atas, ada empat konsep yang ditemukan di dalam TQM yaitu: mutu, kepuasan pelanggan, perbaikan terus menerus, dan melibatkan seluruh komponen organisasi.

1. Mutu

Pada TQM konsep mutu yang digunakan adalah konsep mutu relatif. Dalam konsep relatif, mutu memilki dua aspek. Pertama, produk/jasa yang dihasilkan sesuai dengan spesifikasi. ${ }^{6}$ Kedua, mutu bisa artikan sebagai sesuatu yang bisa memuaskan keinginan dan kebutuhan pelanggan. ${ }^{7}$ Sementara itu, quality in preseption merupakan kepuasan dan bertambahnya minat pelanggan terhadap lulusan lembaga pendidikan. ${ }^{8}$

2. Kepuasan Pelanggan

Dua hal yang sangat menentukan kepuasan pelanggan, yaitu apa yang akan dijadikan sebuah produk? dan siapa yang menjadi pelanggan? Dengan adanya konsep TQM, dunia pendidikan diposisikan sebagai jasa, yakni selalu memberikan pelayanan maksimal sesuai kebutuhan pelanggan. ${ }^{9}$ Dalam hal ini, yang dimaksud produk adalah jasa yang diberikan oleh lembaga pendidikan kepada pelanggan, yang meliputi: pendidikan, bimbingan belajar, penilaian, layanan administrasi. Selain itu, pelanggan dapat dibedakan menjadi dua, yaitu : pertama pelanggan dalam (internal customer), yakni pengelola lembaga pendidikan itu sendiri, misalkan kepala sekolah/manager, guru, staf/tenaga

5 Wahyu Septiadi, Tinjauan Total Quality Management (TQM) pada Lembaga Pendidikan Islam, Nidhomul Haq, Jurnal Manajemen Pendidikan Islam, Vol, 4 No. 1 Tahun 2019, 38.

${ }^{6}$ Edward Sallis, Total Quality Management in Education, (Jogjakarta: Ircisod, 2012), 54-55.

${ }^{7}$ Ibid, 56 .

${ }^{8}$ Nur Zazin, Gerakan menata Mutu Pendidikan Teori E Aplikasi, (Jakarta: arRuzz Media, 2011), 63.

${ }^{9}$ Ibid, 64 . 
kependidikan, pengelola instansi. Kedua, pelanggan luar, misalnya peserta didik, orang tua, masyarakat, pemerintah, dan bursa kerja. ${ }^{10}$ 3. Perbaikan Terus Menerus

Melakukan perbaikan terus menerus ini memang bukanlah hal yang mudah, seorang manajer harus mampu menciptakan kultur perbaikan terus-menerus tersebut. Hal tersebut membutuhkan waktu yang lama. TQM membutuhkan perubahan sikap dan metode. Guru dan staf dalam lembaga pendidikan di wajibkan untuk memahami dan melaksanakan moral TQM agar bisa membawa dampak. Untuk itu seorang manajer/kepala sekolah harus mempercayai guru dan stafnya dan mendelegasikan keputusan pada tingkatan-tingkatan yang tepat. Dalam hal ini bertujuan supaya guru dan staf mempunyai tanggung jawab dalam hal menyampaikan mutu pada lingkungan mereka. Guru dan staf membutuhkan kebebasan dalam kerangka kerja yang sudah jelas dan tujuan organisasi yang sudah diketahui. ${ }^{11}$

4. Melibatkan Seluruh Komponen Organisasi

Melibatkan semua komponen yang ada dalam pelaksanaan TQM merupakan hal yang sangat penting. tentunya terdapat manfaat bagi organisasi, manfaat tersebut antara lain:

a. Menghasilkan keputusan yang baik dan perbaikan yang lebih efektif karena mencakup pemikiran dari pihak yang menangani berhubungan dengan situasi kerja.

b. Dapat memberikan peningkatan pada sikap memiliki dan tanggung jawab.

Kunci sukses TQM adalah adanya kerjasama antara internaleksternal yang efektif. Begitu konsep sudah berhasil dijalankan, maka ada implikasi yang luar biasa terhadap organisasi dan pola hubungan yang ada di dalamnya. Dalam TQM peran kepala sekolah adalah selalu memberikan wewenang kepada Guru dan staf serta pelajar, bukan hanya mengawasi atau mengkontrol mereka.

${ }^{10}$ Umiarso \& Imam Gojali, Manajemen Mutu Sekolah di Era Otonomi Pendidikan, (Jogjakarta: Ircisod, 2011), 137.

${ }^{11}$ Sallis, Total Quality Management..., 77. 
Di samping itu terdapat juga ketentuan TQM untuk meningkatkan kualitas mutu, yaitu: ${ }^{12}$ fokus pada pelanggan, baik pelanggan internal maupun eksternal; memiliki obsesi yang tinggi terhadap kualitas, menggunakan pendekatan ilmiah dalam pengambilan keputusan dan pemecahan masalah, memiliki komitmen jangka panjang, membutuhkan saling kerjasama tim, menyelenggarakan pendidikan dan pelatihan, memberikan kebebasan tetapi dalam pengawasan, adanya keterlibatan dan pemberdayaan karyawan.

\section{Mutu Pendidikan}

Mutu dalam manajemen mempunyai arti kualitas. ${ }^{13}$ Dalam bahasa Inggris, mutu diistilahkan dengan "quality". ${ }^{14}$ Sedangkan dalam bahasa Arab dikenal dengan istilah "juudah". ${ }^{15}$ Secara istilah mutu menunjukan kepada sesuatu ukuran penilaian atau penghargaan yang diberikan suatu jasa. ${ }^{16}$ Konsep mutu mengandung pengertian keunggulan suatu produk baik berupa barang maupun jasa. ${ }^{17}$

Berdasarkan pengertian di atas, mutu mempunyai makna yaitu ketentuan dan penilaian tentang kualitas suatu barang maupun jasa yang mempunyai standar tinggi atau rendah. Mutu yang berstandar tinggi pasti tidak dapat diungguli. Biasanya disebut dengan baik, unggul, cantik, bagus, mahal, dan sebagainya. ${ }^{18}$ Dari uraian diatas dapat disimpulkan bahwa mutu adalah ilmu atau seni

${ }_{12}$ Hadari Nawawi, Manajemen Strategik Organisasi Non Profit Bidang Pemerintahan dengan Ilustrasi di Bidang Pendidikan, (Yogyakarta: Gajah Mada University Press, 2003), 127.

${ }^{13}$ Pius Partanto \& Dahlan Albari, Kamus Ilmiah Populer, (Surabaya: Arloka, 2001), 510.

${ }^{14}$ Peter Salim, The Contemporary English Indonesian Dictionary, (Jakarta: Modern English Press, 1987), 550.

${ }^{15}$ Attabik Ali, Kamus Inggris-Indonesia-Arab, (Yogyakarta: Mukti Karya Grafika, 2003), 1043.

${ }^{16}$ Aan Komariah dan Cepi Triatna, Visionary Leadership: Menuju Sekolah Efektif, (Jakarta: PT. Bumi Aksara, 2008), 9.

${ }^{17}$ B. Suryobroto, Manajemen Pendidikan di Sekolah, (Jakarta: Rieneka Cipta, 2004), 210.

${ }^{18}$ Sallis, Total Quality Management..., 52. 
yang mengatur semua tentang proses pemberdayaan sumber daya manusia atau sumber lainnya yang bisa mendukung dalam pencapaian tujuan secara efektif dan efisien. Pendidikan bermutu adalah pendidikan yang berlandaskan kepada kepuasaan pelanggan sebagai sasaran utama. Pelanggan pendidikan ada dua aspek, yaitu; pelanggan internal dan pelanggan eksternal. ${ }^{19}$

Mutu pendidikan umumnya dapat diukur dari segi input, proses, output maupun outcome. Ada 13 karakteristik yang dapat dinilai dalam hal mutu pendidikan yaitu: kinerja (performan), waktu wajar (timelines), handal (reliability), daya tahan (durability), indah (aesteties), relasi manusiawi (personal interface), mudah penggunaanya (easy of use), bentuk khusus (feature), standar tertentu (comformence to specification), konsistensi (concistency), seragam (uniformity), mampu melayani (serviceability), akurasi (acuracy). ${ }^{20}$

Pada peningkatan mutu pendidikan harus mengambil langkah sebagai berikut:

1. Pemerintah menanggung biaya minimum pendidikan yang diperlukan anak usia sekolah baik negeri maupun swasta yang diberikan kepada siswa secara individual.

2. Optimalisasi sumber daya pendidikan yang sudah tersedia, antara lain melalui double shift (contoh pemberdayaan SMP terbuka dan kelas jauh)

3. Memberdayakan sekolah-sekolah swasta melalui bantuan dan subsidi dalam rangka peningkatan mutu pembelajaran siswa dan optimalisasi daya tampung yang tersedia.

4. Melanjutkan pembangunan Unit Sekolah Baru (USB ) dan Ruang Kelas Baru (RKB) bagi daerah-daerah yang membutuhkan dengan memperhatikan peta pendidiakn di tiap-tiap daerah sehingga tidak mengggangu keberadaan sekolah swasta.

${ }^{19}$ Ibid., 6.

${ }^{20}$ Husaini Usman, Manajemen Teori, Praktek Dan Riset Pendidikan, ( Jakarta : Bumi Aksara, 2006), 411. 
5. Memberikan perhatian khusus bagi anak usia sekolah dari keluarga miskin, masyarakat terpencil, masyarakat terisolasi, dan daerah kumuh.

6. Meningkatkan partisipasi anggota masyarakat dan pemerintah daerah untuk ikut serta menangani penuntasan wajib belajar pendidikan dasar sembilan tahun. ${ }^{21}$

Terdapat empat pilar mutu yang dimaksud yaitu: 1) layanan pelanggan, 2) perbaikan terus-menerus, 3) proses dan fakta-fakta, dan 4) menghormati orang. Setiap lembaga pendidikan masalahnya berbeda tetapi inti permasalahannya sama. Keempat pilar harus ditangani dengan baik dalam rangka meminimalkan kesalahan. Salah satu pilar tidak dijalankan dengan baik dapat meruntuhkan mutu pendidikan secara keseluruhan.

\section{Implementasi TQM di MA Mamba'ul Hisan Sidayu Gresik}

Berdasarkan hasil observasi terkait pelaksanaan TQM di MA Mamba'ul Hisan Sidayu Gresik didapatkan bahwa pelaksanaannya cukup baik, hal ini dibuktikan berdasarkan empat konsep TQM sebagai acuan untuk meningkatkan mutu pendidikan di lembaga tersebut. Akan tetapi yang lebih ditekankan dan di prioritaskan di dalam lembaga tersebut adalah meningkatkan mutu pendidikan.

MA Mamba'ul Hisan Sidayu Gresik berusaha memenuhi kebutuhan para siswa dari beragam kalangan yang ada di lembaga tersebut, satu diantara strategi yang dilakukan lembaga adalah menyediakan 15 jenis kegiatan esktrakulikuler dari berbagai macam bidang kegiatan untuk menyalurkan bakat dan minat siswa. Di samping kegiatan bimbingan bagi siswa yang mempunyai potensi lebih dalam rangka peningkatan mutu pendidikan. Setiap satu semester lembaga mengadakan pertemuan dengan orang tua siswa tujuannya untuk mengetahui kebutuhan siswa dan orang tua sudah terpenuhi apa belum selain itu untuk mengatahui apakah orang tua puas dengan pelayanan yang diberikan oleh lembaga.

\footnotetext{
${ }^{21}$ Indra Djati Sidi, Menuju Masyarakat Belajar, (Jakarta : Logos, 2003), 73.
} 
Pada aspek perbaikan secara terus menerus dan berkelanjutan, di MA Mamba'ul Hisan Sidayu ini menerapkan prinsip-prinsip dan tampak dari berbagai program yang dicanangkan serta strategi yang digunakan dalam peningkatan mutu pendidikan. Diantara program yang di buat adalah pelaksanaan rekrutmen guru berkualitas dan mempunyai keahlian lain, setiap akhir semester lembaga melakukan evaluasi terhadap hasil kinerja guru dan peningkatan kualitas pembelajaran. Strategi lainnya yaitu integrasi unit/sekolah dengan pondok pesantren agar pengawasan bisa dilakukan selama 24 jam baik oleh wali kelas (selama proses KBM) dan oleh pengurus yang ada di pondok (selama di luar proses KBM). Selain program diatas lembaga ini juga mempunyai program lainnya di bidang bahasa Arab dan bahasa Inggris. Strategi yang dilakukan yaitu mengadakan pembinaan atau pembelajaran bahasa Arab maupun bahasa Inggris.

Indikator atau ciri-ciri keberhasilan implementasi TQM pada lembaga pendidikan ini juga ditemukan di MA Mamba'ul Hisan Sidayu Gresik, indikator keberhasilannya adalah sebagai berikut: ${ }^{22}$

1. Sebagai pimpinan, staf dan guru memiliki sikap visioner, pemersatu, pemberdaya, pengendali rasio emosi dan integritas.

2. Memiliki mutu pendidikan dan pengajaran yang bisa membantu peserta didik untuk memperhatikan dan mengembangkan kognitif, afektif, etika, moral, sosial, fisik dan intrapersonal.

3. Memiliki kualitas layanan administrasi yang bagus.

4. Memiliki lulusan cerdas akal, spiritual, emosional dan seimbang antara hard skill dan soft skill serta aktif, kreatif dan inovatif terhadap perkembangan iptek dan lapangan kerja pada saat ini.

\section{Mutu Pendidikan di MA Mamba'ul Hisan Sidayu Gresik}

Berdasarkan hasil penelitian bahwa MA Mamba'ul Hisan Sidayu Gresik kini sudah bermutu, hal ini dapat dilihat dari aspek proses penerimaan siswa baru yang harus melalui dua tes yaitu tes tulis maupun tes lisan, jumlah guru yang dimiliki lembaga cukup

${ }^{22}$ Ifah Khadijah, "Manajemen Mutu Terpadu (TQM) pada Lembaga Pendidikan Islam,” al-Idarah Jurnal Kependidikan Islam, Vol 5 No. 1 Tahun 2015, 71. 
banyak dan mayoritas telah menempuh jenjang pendidikan S1 bahkan S2. Staf TU, konselor dan administrator yang kompeten di bidangnya. Serta tersedianya sarana dan prasarana yang memadai diantaranya ruang kelas, lapangan, laboratorium internet, perpustakaan yang berguna untuk meningkatkan mutu pendidikan. Dalam proses belajar-mengajar, para guru di MA Mamba'ul Hisan Sidayu Gresik kini menggunakan beragam metode belajar, sehingga membuat peserta didik lebih mudah memahami dan tidak jenuh dalam mengikuti materi yang disampaikan.

Berbagai macam dukungan dari stekholder yang ada di lembaga ini bisa dinilai cukup baik, sehingga MA Mamba'ul Hisan Sidayu Gresik ini dapat melahirkan lulusan yang baik dan dapat bersaing ketika hendak melanjutkan ke jenjang perguruan tinggi ternama di Indonesia, selain itu ada juga yang melanjutkan studi fakultas kedokteran, dan ada pula yang langsung berkarier dan mengabdi di TNI, dunia penerbangan, maupun menjadi wirausaha.

Program yang dapat meningkatkan kualitas pendidikan yang ada di MA Mamba'ul Hisan Sidayu Gresik beragam, namun ada dua program yang menjadi karakteristik lembaga ini dan bertujuan siswa kelak menjadi orang yang beragama, tertanam karakter mulia dan akhlaq baik. Kedua program tersebut yaitu: pertama memakai KBM di dalam kelas, para guru pendidik wajib memiliki ketrampilan dan inovasi dalam mengajar, tujuannya supaya siswa tidak merasa jenuh sehingga bisa mengikuti proses pembelajaran dengan semangat; kedua program pendidikan agama, program ini masuk dalam kegiatan ekstrakulikurer agama yaitu belajar membaca Alqur'an yang benar, menghafal juz amma, istighasah, manaqib, shalat dhuha, belajar membaca kitab kuning (setiap bulan Ramadhan). Seluruh program pendidikan agama di sekolah ada keterkaitan dengan kegiatan lainnya yang ada di pondok pesantren. Berbagai macam program kegiatan ini tujuannya untuk memberikan bekal kepada para siswa untuk masa depannya.

Selain kedua program di atas, ada kegiatan ekstrakurikuler yang dapat meningkatkan kualitas pendidikan di MA Mamba'ul Hisan Sidayu Gresik. Pertama kegiatan ekstrakulikuler umum 
seperti kegiatan pramuka, pidato bahasa, sastra bahasa, pencak silat, futsal, dan lain-lain. Kedua kegiatan ekstra kulikuler agama seperti belajar membaca Alqur'an yang benar, menghafal juz amma, istighasah, manaqib, shalat dhuha, belajar membaca kitab kuning (setiap bulan Ramadhan). Semua program/ kegiatan ini sudah diterapkan selama lima tahun terakhir di MA Mamba'ul Hisan Sidayu Gresik dan tujuannya adalah mengembangkan bakat siswa sehingga kelak bisa bermanfaat untuk masa depan siswa itu sendiri.

\section{Simpulan}

TQM merupakan suatu sistem menejemen yang melibatkan seluruh komponen organisasi dan dilakukan secara terus menerus untuk menghasilkan produk/jasa yang bermutu/berkualitas sesuai dengan kebutuhan pelanggan dan berorientasi pada kepuasan pelanggan. Terdapat empat konsep dalam TQM yang sudah diterapkan oleh MA Mamba'ul Hisan Sidayu Gresik, tujuannya untuk meningkatkan kualitas mutu pendidikan, empat konsep antara lain: mutu, kepuasan pelanggan, perbaikan terus menerus, dan melibatkan seluruh komponen organisasi.

Madrasah Aliyah Mamba'ul Hisan Sidayu Gresik memiliki kegiatan ekstrakulikuler yang bertujuan untuk meningkatkan mutu pendidikan di lembaga tersebut, kegiatan meliputi dua program/ kegiatan yaitu: pertama kegiatan ekstrakulikuler umum seperti kegiatan pramuka, pidato bahasa, sastra bahasa, pencak silat, futsal dll, Kedua kegiatan ekstrakulikuler agama seperti belajar membaca Alqur'an yang benar, menghafal juz amma, istighasah, manaqib, shalat dhuha, belajar membaca kitab kuning (setiap Ramadhan).

\section{Referensi}

Ali, Attabik, Kamus Inggris-Indonesia-Arab, Yogyakarta: Mukti Karya Grafika, 2003

Burnham, West, Managing Quality in School, London: Prentice Hall, 1997.

Khadijah, Ifah, "Manajemen Mutu Terpadu (TQM) pada Lembaga Pendidikan Islam," Al-Idarah Jurnal Kependidikan Islam, Vol 5 No. 1 Tahun 2015. 
Komariah, Aan dan Cepi Triatna, Visionary Leadership: Menuju Sekolah Efektif, Jakarta: PT. Bumi Aksara, 2008.

Majid, Abdul, Pendidikan Agama Islam (KBK 2004), Bandung: Remaja Rosda Karya, 2004.

Munir, Miftakhul, "Keberadaan Total Quality Management dalam Lembaga Pendidikan (antara Prinsip Implementasi dan Pilar TQM dalam Pendidikan)," Realita, Vol. 16, No. 1 Tahun 2018.

Nawawi, Hadari, Manajemen Strategik Organisasi Non Profit Bidang Pemerintahan dengan Ilustrasi di Bidang Pendidikan, Yogyakarta: Gajah Mada University Press, 2003.

Partanto, Pius \& Dahlan Albari, Kamus Ilmiah Populer, Surabaya: Arloka, 2001.

Salim, Peter, The Contemporary English Indonesian Dictionary, Jakarta: Modern English Press, 1987.

Sallis, Edward, Total Quality Management in Education, Jogjakarta: Ircisod, 2012.

Sani, Ridwan Abdullah, Isda Pramuniati, Anise Mucktiany, Penjaminan Mutu Sekolah, Jakarta: Bumi Aksara, 2015.

Septiadi, Wahyu, "Tinjauan Total Quality Management (TQM) pada Lembaga Pendidikan Islam," Nidhomul Haq, Jurnal Manajemen Pendidikan Islam, Vol, 4 No. 1 Tahun 2019.

Sidi, Djati Indra, Menuju Masyarakat Belajar, Jakarta: Logos, 2003

Suryobroto, B., Manajemen Pendidikan di Sekolah, Jakarta: Rieneka Cipta, 2004.

Tafsir, Ahmad, Ilmu Pendidikan dalam Perspektif Islam, Bandung: Remaja Rosdakarya, 1992.

Umiarso \& Imam Gojali, Manajemen Mutu Sekolah di Era Otonomi Pendidikan, Jogjakarta: Ircisod, 2011.

Usman, Husaini, Manajemen Teori, Praktek dan Riset Pendidikan, Jakarta: Bumi Aksara, 2006.

Zazin, Nur, Gerakan Menata Mutu Pendidikan Teori $\mathcal{E}$ Aplikasi, Jakarta: ar-Ruzz Media, 2011.

Zuhairini, dkk., Metodologi Pendidikan Agama 1, Solo: Ramadhani, 1993. 